Psikiyatri hastasına bakım veren hemşirelerde ahlaki duyarlılık: Tanımlayıcı-kesitsel tipte bir çalışma

\title{
Moral Sensitivity in Nurses Providing Care to Psychiatric Patients: A cross- sectional study
}

\section{Songül Duran', Maral Kargın², Evrim Çelebi ${ }^{3}$}

1Trakya Üniversitesi, Keşan Hakkı Yörük Sağlık Yüksekokulu, Hemşirelik Bölümü, Edirne, Türkiye 2Fırat Üniversitesi, Sağlık Bilimleri fakültesi, Hemşirelik Bölümü, Elazığ, Türkiye 3Fırat Üniversitesi, Sağlık Bilimleri fakültesi, Ebelik Bölümü, Elazığ, Türkiye

\section{$\ddot{O} Z$}

YÖNTEM ve GEREÇLER: Tanımlayıcı ve kesitsel tipteki bu araştırma, Nisan - Temmuz 2017 tarihleri arasinda gerçekleştirilmiștir. Bu araştırmanın örneklemini, Türkiye'de Doğu Anadolu bölgesinde yer alan ve 3. basamak sağllk hizmeti veren bir ruh sağllğı hastanesi ve toplum ruh sağllğg Merkezi'nde çalışan 105 hemşire oluşturmuştur. Veriler Kişisel Bilgi Formu ve Ahlaki Duyarlılık Anketi (ADA) ile toplanmıştır.

BULGULAR: Çalışmaya katılan hemşirelerin ahlaki duyarlılıklarının yüksek düzeyde olduğu saptanmıştır. Toplam ADA puanının cinsiyet, eğitim durumu, servisteki görevleri, serviste çalışma yll ve mesleği sevme durumuna göre istatistiksel açıdan anlamlı fark oluşturmadığı belirlenmiştir. 30 yaş ve altı hemşirelerin 30 yaşın üstündeki hemşirelere göre, bekar hemşirelerin ise evli hemşirelere göre oryantasyon alt boyutu puanlarının daha yüksek olduğu belirlenmiştir.

TARTIŞMA ve SONUÇ: Hemşirelerde ahlaki duyarlılı̆̆ın oluşturulması, devam ettirilmesi ve geliştirilmesi için psikiyatri hemşireliği eğitiminde ve uygulamasında yetkinlik ve sorumluluk oluşturulması, mezuniyet sonrası hizmet içi eğitimlerin düzenli olarak verilmesi önerilebilir.

Anahtar Kelimeler: Ahlaki duyarlılık, etik, etik duyarlılık, psikiyatri hemşireliği.

\section{ABSTRACT}

INTRODUCTION: In this study, it was aimed to determine the moral sensitivity of nurses who give care to psychiatric patients.

METHODS: This descriptive and cross-sectional study was conducted between April and July 2017. The sample of this research, a field that mental health care in the Eastern Anatolia region in Turkey and 3 consisted of 105 nurses working in hospitals and community mental health center. Data were collected via Personal Information Form and Moral Sensitivity Questionnaire.

RESULTS: The nurses participating in the study were found to have high levels of moral sensitivity. It was determined that orientation subscale scores of 30 year old and younger nurses comparing with nurses older than 30 and single nurses comparing with married ones were determined as higher.

DISCUSSION AND CONCLUSION: Competence and responsibility creation in psychiatric nursing education and practice, and providing regular in-service training after graduation may be advised to create, maintain and improve moral sensitivity of nurses.

Keywords: Moral sensitivity, ethic, ethical sensitivity, psychiatric nursing

İletişim / Correspondence:

Songül Duran

Trakya Üniversitesi, Keşan Hakk Yörük Sağllk Yüksekokulu, Hemşirelik Bölümü, Edirne, Türkiye

E-mail:songul.duran@gmail.com

Başvuru Tarihi: 09.05.2018

Kabul Tarihi: 06.10.2018 


\section{INTRODUCTION}

Nursing is a profession that deals with the most personal and special aspects of human life. Therefore, nurses are expected to be aware of the valid ethical aspects while meeting the health care needs of the individuals and the society (1). Nurses, who have various responsibilities in the provision of healthcare services quite often experience ethical dilemmas primarily against individual in regard to the responsibility of patient care and resuming treatment (2).

Nurses are expected to have the ability to make the right decisions in the face of these ethical dilemmas. However, recognition and analysis of ethical issues to reach the right decisions require the development of ethical sensitivity characterized as the ability to distinguish an ethical issue (3).

Ethical sensitivity is defined as the capacity of healthcare professionals to understand the patients they care for and the method they employ in providing good care (4). Ethical sensitivity is the professional aspect of moral sensitivity $(5,6)$. While moral sensitivity originates from insight and benevolence, the source of ethical sensitivity is awareness of one's professional role and responsibilities, knowledge of professional ethics, and ethical standards. It is impossible to completely dissociate these two concepts (5). Moral sensitivity is the capacity to identify an ethical issue and to understand the ethical consequences of decisions made on behalf of the patient (7). Nurses should be responsive to the physical and emotional needs of patients and address these needs as part of the care process (4).

Psychiatric clinics are one of the places where ethical dilemmas and issues in ethical decisionmaking are experienced frequently. Having to make decisions regarding a patient with impaired autonomy (8), actions to be taken in cases where treatment is rejected, involuntary hospitalization, identification of agitated patients, and administration of involuntary treatment to suicideattempt survivors who reject treatment are some of the subjects that cause ethical dilemma and conflict $(9,10)$.Attaining a balance between patient autonomy and the need for unit control, as well as, doing the right thing for the patient are among the most common ethical problems psychiatric nurses encounter (11). Working at a psychiatric clinic can be exhausting for nurses due to ethical difficulties. The contradictory nature of providing care in a psychiatric clinic can create stress in nurses and lead to feelings of inadequacy and qualms of conscience (12).

Another important characteristic of psychiatric ethics is the urgency and unpredictability of situations that might arise. Each case is unique and practice might vary by person or situation. In emergencies, there is a difference between knowing what to do and knowing how to do it. In this scenario, what is to be done involves theoretical knowledge but how it is to be done denotes the significance of individual qualities in the decisionmaking process (7). Ethical decision-making is not only a procedure the practitioner ought to follow but also the immediate understanding of the patient's vulnerability and an awareness of the moral implications of deciding on the patient's behalf $(7,13)$.

Psychiatric nurses should respect and protect the patient's right to make decisions, be sensitive to ethical issues and handle ethical problems and dilemmas effectively in clinical practice. 14 However, nurses' efforts to balance fulfilling patient needs and maintaining order in the clinic can lead to unethical behavior. Nurses can be more result-oriented during nursing practice. They can violate ethical norms (e.g. informed consent, confidence, and patient autonomy), damaging the therapeutic relationship (15).

It is critical for nurses providing care to psychiatric patients, who might not be aware of their physical and mental needs and who lack competence in these subjects, to act in compliance with ethical principles (15). Nurses with high ethical sensitivity recognize ethical problems and make right decisions much more easily (3).

Moral distress reduces quality of care, decreases patient satisfaction (16) and causes physical and psychological problems (17). It may result in problematic consequences for nurses, patients and the overall health system. A morally distressed nurse experiences anger, guilt (18), sorrow, frustration and anxiety, which can generate 
dissatisfaction and burnout and even lead to leaving the profession $(19,20)$.

The level of moral distress experienced by nurses who care for a psychiatric patient can vary from one country / culture / institution to another. For this reason, there is a need for new studies in the international arena. In a study conducted with nurses working in the psychiatry service in Turkey; respect for the autonomy of the patient, privacy, usefulness, maltreatment and justice has been found to be between the ethical problems faced (21).

In a study conducted by Eren in five hospitals in Turkey, causes of nurses' ethical problems have been detected as over activity, inadequate number of nurses working in shifts, lack of communication, inadequacy in nursing education, complicated structure of psychiatric care, tendency of medical doctors to stand against group work, personal characteristics of health workers, lack of policy and process, intolerance, insufficient control, anxiety about error recording (15).

Determining moral sensitivity in nurses who provide care to psychiatric patients is significant in terms of prevention, support and education. The number of Turkish studies that investigate moral sensitivity in nurses who provide care to psychiatric patients is quite limited. Therefore, this study constitutes an important source of data as it involves an extensive sample of nurses employed at a psychiatric hospital and a community mental health center that provide healthcare services to only psychiatric patients. Culturally comparative studies regarding that how nurses cope with their own experiences are necessary to enhance the understanding of cultural contexts. It is thought that descriptive studies to increase the nurses' moral sensitivity will be a guide.

This study was aimed at investigating moral sensitivity in nurses providing care to psychiatric patients. This study seeks to answer the following questions:

What is the level of moral sensitivity of nurses providing care to psychiatric patients?

What are the socio-demographic characteristics that affect moral sensitivity in nurses providing care to psychiatric patients?

\section{MATERIALS AND METHODS}

\section{Study design and sample}

This descriptive cross-sectional study investigated the level of moral sensitivity of nurses working at a regional psychiatric hospital and a community mental health center in eastern Turkey. This research was conducted between April and July 2017. The universe of the research is composed of 185 nurses working in this hospital. $57 \%$ of the universe was reached. Those who did not agree to participate in the study and did not want to fill out the survey were not included in the study. The study sample (105 nurses) comprised the nurses working at the psychiatric hospital and the community mental health center. The researchers did not employ sampling and tried to contact every nurse who was not on annual or sick leave. The nurses who agreed to participate and gave verbal consent were included in the study. Research commenced after approval from the institutions.

\section{Ethical approval}

Approval for this study was obtained from Furat University Non-Interventional Research Ethics Committee of Firat University (30.03.2017-Meeting Number 06-Decision Number 20). In addition, permission was acquired from Tosun to use the Moral Sensitivity Questionnaire.

\section{Measurements}

The Demographic Information Form developed by the researchers and the Moral Sensitivity Questionnaire was used in data collection. The Demographic Information Form comprised questions on age, education, gender, marital status, length of service, whether or not the respondents had attended ethics education, etc.

Moral Sensitivity Questionnaire (MSQ): The MSQ was used by Kim Lützen (1994) to investigate ethical sensitivity in physicians and nurses initially in psychiatric clinics and later in other clinics (3). It was adapted to Turkish in 2005 by Hale Tosun (2005) and the Cronbach's Alpha was computed as 0.84 . The scale comprises 30 items and six subscales, with three items (items 3, 23 and 26) not part of any subscale. The subscales are autonomy (respect for the patient's self-choice and the principle of autonomy), benevolence (moral 
motivation to act in the best interest of the patient), meaning (making moral meaning of actions that protect the patient's integrity and do not harm to the patient), conflict (experiencing moral conflict), practice (trust in medical knowledge and principles of care) and relational orientation (healthcare professional's concern as to how actions will affect the relationship with the patient) $(22,23)$. On the 7 point Likert-type scale, a rating of 1 (completely agree) indicates high sensitivity while a rating of 7 (completely disagree) signifies low sensitivity (2). The minimum and maximum possible MSQ overall scores are 30 and 210 , respectively, where a low score indicates high ethical sensitivity and a high score infers low ethical sensitivity (3).

\section{Data analysis}

The study data were analyzed with SPSS 17 software package. The data were presented as number, percentage and mean. An independent samples t-test and an analysis of variance (ANOVA) were used in data analysis. The significance level was set at $\mathrm{p}<0.05$.

\section{Limitations of the Study}

This study was conducted in one institution, which is among the study limitations. Thus, it is not possible to generalize these study results. In the institution, approximately $57 \%$ of nurses were reached. For that reason, sampling cannot be generalized. Therefore, it is suggested that further studies be conducted by taking these deficiencies into consideration, and in different institutions.

\section{RESULTS}

The results obtained from the study data are presented in this section. Mean nurse age was computed as $34.7 \pm 7.3$. Various descriptive characteristics of the respondents are given in Table $1.62 .9 \%$ of the nurses were in the $30-40$ age group, $63.8 \%$ were female, $75.2 \%$ were married and $59 \%$ had an undergraduate degree. In addition, $85.7 \%$ worked as a clinic nurse and $33.3 \%$ had 6-10 years of service. $69.5 \%$ of the nurses reported that they loved and were devoted to their profession.

\begin{tabular}{|c|c|c|}
\hline Demographic Characteristics & Number & $\%$ \\
\hline \multicolumn{3}{|l|}{ Age } \\
\hline $19-29$ years-old & 23 & 21.9 \\
\hline $30-40$ years-old & 66 & 62.9 \\
\hline 40 years-old or older & 16 & 15.2 \\
\hline \multicolumn{3}{|l|}{ Gender } \\
\hline Female & 67 & 63.8 \\
\hline Male & 38 & 36.2 \\
\hline \multicolumn{3}{|l|}{ Marital Status } \\
\hline Married & 79 & 75.2 \\
\hline Single & 26 & 24.8 \\
\hline \multicolumn{3}{|l|}{ Educational } \\
\hline Vocational school of health degree & 19 & 18.1 \\
\hline Associate degree & 19 & 18.1 \\
\hline Undergraduate degree & 62 & 59.0 \\
\hline Master's degree & 5 & 4.8 \\
\hline \multicolumn{3}{|l|}{ Job position } \\
\hline Supervisor nurse & 15 & 14.3 \\
\hline Clinic nurse & 90 & 85.7 \\
\hline \multicolumn{3}{|l|}{ Length of service } \\
\hline $1-5$ years & 15 & 14.3 \\
\hline $6-10$ years & 35 & 33.3 \\
\hline $11-15$ years & 27 & 25.7 \\
\hline $16-20$ years & 11 & 10.5 \\
\hline 20 years or more & 17 & 16.2 \\
\hline \multicolumn{3}{|l|}{ Do you love your profession? } \\
\hline Yes & 73 & 69.5 \\
\hline No & 13 & 12.4 \\
\hline Undecided & 19 & 18.1 \\
\hline
\end{tabular}

Mean overall score was computed as $73.7 \pm 16.0$ (minimum 37, maximum 128). Mean subscale scores for the autonomy, benevolence, meaning, conflict, practice and relational orientation subscales were $17.1 \pm 5.50,12.2 \pm 3.7,11.5 \pm 3.7$, $12.5 \pm 3.5, \quad 11.2 \pm 3.5$ and $9.2 \pm 3.8$; respectively (Table 2). 


\begin{tabular}{|l|c|c|}
$\begin{array}{l}\text { Table 2. Distribution of MSQ overall and } \\
\text { Subscale mean scores }\end{array}$ \\
$\begin{array}{l}\text { MSQ Subscale (min-max } \\
\text { possible scores) }\end{array}$ & Mean \pm SD & Min-Max \\
\hline Autonomy (7-49) & $17.1 \pm 5.5$ & $8-39$ \\
\hline Benevolence (4-28) & $12.2 \pm 3.7$ & $4-20$ \\
\hline Meaning (5-35) & $11.5 \pm 3.7$ & $5-22$ \\
\hline Conflict (3-21) & $12.5 \pm 3.5$ & $3-20$ \\
\hline Practice (4-28) & $11.2 \pm 3.5$ & $4-22$ \\
\hline Relational Orientation $\quad(4-$ & $9.2 \pm 3.8$ & $4-20$ \\
\hline 28) & & \\
\hline Overall (30-210) & $73.7 \pm 16.0$ & $37-128$ \\
\hline
\end{tabular}

Table 3 shows the distribution of MSQ overall and subscale mean scores by age group. There was no significant difference in autonomy, benevolence, meaning, conflict and practice subscale mean scores or overall mean scores with respect to age ( $p>0.05$ ). However, nurses aged 30 years or under had a lower relational orientation subscale mean score than nurses who were older than 30 years and this difference was found to be statistically significance.

\begin{tabular}{|c|c|c|c|c|}
\hline \multirow{3}{*}{$\begin{array}{l}\text { MSQ overall } \\
\text { and subscale }\end{array}$} & \multicolumn{3}{|c|}{ Age group } & \multirow{3}{*}{$\mathrm{p}$} \\
\hline & $\begin{array}{l}<30 \\
\text { years-old }\end{array}$ & $\begin{array}{l}30-40 \\
\text { years-old }\end{array}$ & $\begin{array}{l}>40 \\
\text { years-old }\end{array}$ & \\
\hline & Mean $\pm S D$ & Mean $\pm S D$ & Mean $\pm S D$ & \\
\hline Autonomy & $15.2 \pm 4.7$ & $17.6 \pm 5.6$ & $17.9 \pm 5.7$ & 0.152 \\
\hline Benevolence & $12.2 \pm 3.4$ & $12.5 \pm 4.1$ & $11.2 \pm 2.7$ & 0.464 \\
\hline Meaning & $10.2 \pm 3.1$ & $11.8 \pm 3.9$ & $11.9 \pm 3.6$ & 0.194 \\
\hline Conflict & $12.7 \pm 3.2$ & $12.4 \pm 3.5$ & $12.4 \pm 4.3$ & 0.931 \\
\hline Practice & $10.7 \pm 2.2$ & $11.6 \pm 3.8$ & $10.6 \pm 3.3$ & 0.403 \\
\hline $\begin{array}{l}\text { Relational } \\
\text { Orientation }\end{array}$ & $\underline{7.6 \pm 2.4^{*}}$ & $9.8 \pm 4.1$ & $9.0 \pm 3.7$ & $0.046 *$ \\
\hline Overall & $68.5 \pm 11.6$ & $75.7 \pm 16.9$ & $73.0 \pm 16.3$ & 0.175 \\
\hline$* p<0.05$ & & & & \\
\hline
\end{tabular}

Investigation of the distribution of MSQ overall and subscale mean scores by marital status revealed a significant difference in the relational orientation subscale, where single nurses had lower (i.e. more favorable) scores than married nurses $(\mathrm{p}<0.05)$. The distribution of MSQ overall mean scores and autonomy, benevolence, meaning, conflict and practice subscale mean scores with respect to marital status were approximate ( $p>0.05$, Table 4$)$. MSQ overall and subscale mean scores did not display any statistically significant difference with respect to gender, education, job position, length of service and professional devotion ( $p>0.05$ ).

\begin{tabular}{|c|c|c|c|}
\hline \multirow[b]{3}{*}{$\begin{array}{l}\text { MSQ overall } \\
\text { and } \\
\text { subscale }\end{array}$} & \multicolumn{2}{|c|}{ Marital Status } & \multirow{3}{*}{$p$} \\
\hline & Married & Single & \\
\hline & Mean $\pm S D$ & Mean $\pm S D$ & \\
\hline Autonomy & $17.6 \pm 5.6$ & $16.5 \pm 5.3$ & 0.476 \\
\hline Benevolence & $12.3 \pm 3.8$ & $11.9 \pm 3.6$ & 0.644 \\
\hline Meaning & $11.7 \pm 3.7$ & $10.7 \pm 3.8$ & 0.206 \\
\hline Conflict & $12.5 \pm 3.6$ & $12.5 \pm 3.2$ & 0.943 \\
\hline Practice & $11.4 \pm 3.6$ & $10.6 \pm 2.9$ & 0.284 \\
\hline $\begin{array}{l}\text { Relational } \\
\text { Orientation }\end{array}$ & $9.7 \pm 3.9$ & $\underline{7.6 \pm 2.9}$ & $0.013^{*}$ \\
\hline Overall & $75.0 \pm 16.2$ & $70.0 \pm 14.8$ & 0.146 \\
\hline
\end{tabular}

\section{DISCUSSION}

Many psychiatric nurses experience difficulty in engaging with ethical issues in psychiatry (24). In order to mitigate the negative impact of moral distress on nurses, patients and institutions, the current level of moral distress and the factors that act on moral distress should be identified.

Moral sensitivity is a nurse's ability to discern and distinguish ethical issues in order to analyze these issues and to reach right decisions (25). Therefore, a high level of moral sensitivity in nurses is essential for recognizing ethical issues, making the right decision and taking the right action. The present study found a high level of moral sensitivity among nurses providing care to psychiatric patients. In the validation study of a Korean version of the MSQ, which revealed similar 
results with the present study, Han et al. (2010) found a generally high level of moral sensitivity in Korean nurses. Investigation of similar studies mostly yielded a moderate level of moral sensitivity among nurses (26). Tosun (2) and Ergene (27) reported a moderate level of moral sensitivity for nurses working at psychiatric clinics. Aksu et al. (28), Tural Büyük et al. (29), Filizöz et al. (22) and Daşbilek (25) are some other studies that found a moderate level of moral sensitivity among nurses. Borhani et al. reported higher MSQ scores (i.e. lower moral sensitivity) for psychiatric nurses in comparison to nurses working at other clinics (30). The high level of moral sensitivity among nurses found in the present study is a desirable result that needs to be promoted.

In the present study, nurses aged 30 years or under were found to have a better (i.e. lower) MSQ relational orientation subscale mean score than those who were older than 30 years. Better orientation results among younger nurses is an expected finding as advancing age makes orientation more difficult and may impair the relationship with the patient. Young nurses are generally more active in the clinic, which might be a factor that favorably affects their moral sensitivity. In-service training programs aimed at improving interpersonal orientation can be organized for older nurses. Parallel to the present study, Taylan (2013) identified lower relational orientation subscale scores for 40-year-old or older staff and a statistically significant difference with other age groups (5). In their study with psychiatric nurses, Lützen et al. (2010) revealed that nurses in the 44-54 age group had greater difficulty in emotionally coping with patient suffering in comparison to nurses aged 43 years or younger and felt less satisfied with their nursing care in the last month than other age groups (31). Kurılmaz et al. investigated ethical sensitivity among healthcare staff and, unlike the present study, reported higher relational orientation subscale scores for staff aged 41 years or older than 26-35-year-old staff (32). Aksu et al. (2011) found lower relational orientation subscale scores for nurses aged 18-24 years compared to other age groups (28).

The study results revealed better MSQ relational orientation subscale scores for single nurses in comparison to married nurses. MSQ overall mean scores and autonomy, benevolence, meaning, conflict and practice subscale mean scores did not display any significant difference with respect to marital status. Başak et al. (2010) found that the marital status of nurses was not a factor that acted on MSQ overall and subscale mean scores (33).

\section{CONCLUSION}

In conclusion, the psychiatric nurses who participated in the study had high levels of moral sensitivity. Age and marital status affected particularly the relational orientation dimension of moral sensitivity. The distribution of the Moral Sensitivity Questionnaire overall mean score and other subscale mean scores did not display any significant difference. Regular in-service training should be organized after graduation to maintain and promote moral sensitivity in nurses. Furthermore, more comprehensive studies can be conducted to identify other factors that affect the moral sensitivity of nurses. It is also recommended that interventional studies should be carried out to increase the moral sensitivity of the nurses.

The study results are limited to the group of nurses who participated in the study and cannot be generalized to the entirety of the nurses working at psychiatric clinics.

\section{Acknowledgments}

We would like to thank all nurses who volunteered to participate in this research study.

\section{REFERENCES}

1. Kutlu FY. Çocuk-ergen ruh sağlığı ve psikiyatri hemşireliği uygulamalarında etik ve yasal boyut [The ethical and legal issues in practise of child and adolescent mental health and psychiatric nursing]. Türkiye Klinikleri [J Psychiatr NursSpecial Topics] 2015; 1(2): 100-6. 7 (in Turkish).

2. Tosun H. Sağlık bakımı uygulamalarında deneyimlenen etik ikilemlere karşı hekim ve hemşirelerin duyarlılıklarının belirlenmesi [Determining sensitivity of the nurses and the physicians against the ethic dilemmas which experienced at the health care practices]. Yüksek 
lisans tezi [Master thesis], İstanbul [İstanbul University] Üniversitesi, İstanbul, 2005 (in Turkish).

3. Dalcal1-Köktür B, Şendir M. Hemşirelerin kişisel değerleri ile etik duyarlılıkları arasındaki ilişkinin belirlenmesi. [Determining the relationship between nurses' personal values and their ethical sensitivity]. F.N. Hem. Derg [FNJN] 2016; 24(1): 1-9 (in Turkish).

4. Dikmen Y. Yoğun bakım hemşirelerinde etik duyarlılı̆̆ın incelenmesi [An Observation on The Moral Sensibility of Intensive Care Nurses]. Cumhuriyet Hem Der [Cumhuriyet Nurs J] 2013; 2(1): 1-7 (in Turkish).

5. Taylan S. Acil sağlı ekibinin ahlaki duyarl111klarının belirlenmesi [Identification of moral sensitivity of emergency health teams]. Yüksek Lisans tezi [Master thesis], Çukurova Üniversitesi [Çukurova University], Adana, 2013 (in Turkish).

6. Karadağlı F. Profesyonel hemşirelikte etik [Ethics in Professional nursing]. Düzce Üniversitesi Sağlık Bil Enst Derg [J DU Health Sci Inst] 2016; 6(3): 197-200 (in Turkish).

7. Lützen $K$, Evertzon M, Nordin C. Moral sensitivity in psychiatric practice. Nursing Ethics 1997; 4(6): 472-482.

8. Lützén K, Nordin C. The influence of gender, education and experience on moral sensitivity in psychiatric nursing: a pilot study. Nurs Ethics 1995; 2(1): 41-50.

9. Choe K, Song EJ, Jung CH. Ethical problems experienced by psychiatric nurses in Korea. Arch Psychiatr Nurs 2012; 26(6): 495-502.

10.Arslantaş H. Ruh sağlı̆̆1 ve psikiyatri hemşireliğinde etik konular, kodlar ve standartlar [Ethical Issues, Codes, and Standards In Mental Health and Psychiatric Nursing]. Psikiyatri Hemşireliği Dergisi [J Psy Nurs] 2015; 6(1): 47-56 (in Turkish).

11. Grace PJ, Fry ST, Schultz GS. Ethics and human rights issues experienced by psychiatric-mental health and substance abuse registered nurses. $\mathbf{J}$ Am Psychiatr Nurses Assoc 2003; 9(1): 17-23.

12. Tuwesson H, Eklund M, Wan-Hansson C. Stress of conscience among psychiatric nursing staff in relation to environmental and individual factors. Nurs Ethics 2012; 19(2): 208-219.
13. Lützen K, Ewalds-Kwitz B. Moral Distress and its interconnection with moral sensitivity and moral resilience: viewed from the philosophy of Viktor E. Frankl. Bioethical Inquiry 2013; DOI 10.1007/s11673-013-9469-0.

14. Boonyamanee B, Suttharangsee W, Chaowalit A et al. Exploring moral sensitivity among Thai psychiatric nurses. SJN 2014; 34 (Supplement): 35-43.

15. Eren N. Nurses' attitudes toward ethical issues in psychiatric inpatient settings. Nurs Ethics 2014; 21(3): 359-373.

16. Kertchok R. Ethical İssues and moral distress in psychiatric and mental health nursing: A literature review. J Health Res 2015; 29 (3): 227-234.

17. Ando M, Kawano M. Responses and results to ethical problems by psychiatric nurses in Japan. Archives of Psychiatric Nursing 2016; 30: 527530.

18. Ohnishi K, Ohgushi Y, Nakano M, et. al. Moral distress experienced by psychiatric nurses in Japan. Nurs Ethics 2010; 17(6), 726-740.

19. Schluter J, Winch S, Holzhauser K. Et al. Nurses' moral sensitivity and hospital ethical climate: a literature review. Nurs Ethics 2008; 15(3): 304-321. doi: 10.1177/0969733007088357.

20. Soleimani MA, Sharif SP, Yaghoobzadeh A, et al. Psychometric evaluation of the moral distress scale-revised among Iranian Nurses. Nurs Ethics 2016; 25: 1-17.

21. Aydin Er, Ersoy N (2017). Ethical problems experienced by nurses who work in psychiatry clinics in Turkey. J Psy Nurs 8(2): 77-85.

22. Filizöz B, Mesci G, Aş̧̧ı A, et al. Hemşirelerde etik duyarlıl1k: Sivas ili merkez kamu hastanelerinde bir araştırma [Nurses' Ethical Sensitivity: Research on Central Public Hospitals in Sivas Province]. İş Ahlakı Dergisi [Turkish Journal of Business Ethics] 2015; 8(1): 47-66 (in Turkish).

23. Lutzen K, Johansson A, Nordström G. Moral sensitivity: some differences between nurses and physicians. Nurs Ethics 2000; 7(6): 520-530.

24. Roberts M. Psychiatric ethics; A critical introduction for mental health nurses. J Psychiatr Ment Health Nurs 2004; 11: 583-588. 
25. Daşbilek F. Hemşirelerin kişisel değerleri ile etik duyarlılıklarının bazı değişkenler açısından incelenmesi [Investigation of Some Variables Ethics Awareness and Personal Values of Nurses]. Yüksek lisans tezi [Master thesis], Atatürk Üniversitesi [Atatürk University], Erzurum, 2016 (in Turkish).

26. Han SS, Kim J, Kim YS. et al. Validation of a Korean version of the moral sensitivity questionnaire. Nurs Ethics 2010; 17(1): 99-105.

27. Ergene Z. Psikiyatri kliniklerinde çalışan hemşirelerin etik duyarlılıkları [The ethics sensitivity of nurses working in psychiatric clinics]. Yüksek Lisans tezi [Master thesis], Haliç Üniversitesi [Haliç University], İstanbul, 2012.

28. Aksu T, Akyol A. İzmir'deki hemşirelerin etik duyarlılıklarının incelenmesi [Investigation of the moral sensibility of nurses in İzmir]. Türkiye Klinikleri [J Med Ethics] 2011;19(1):16-24 (in Turkish).

29. Tural Büyük T, Rizalar S, Güdek E. Ethical sensitivity, job satisfaction and related factors of the nurses working in different areas. Prog Health Sci 2015; 5 (1): 138-149.

30. Borhani F, Keshtgar M, Abbaszadeh A. Moral self-concept and moral sensitivity in Iranian nurses. J Med Ethics Hist Med 2015; 8 (4): 2-7.

31. Lützen K, Blom T, Ewalds Kvist B, et al. Moral stress, moral climate and moral sensitivity among psychiatric professionals. Nurs Ethics 2010; 17(2): 213-224. doi: 10.1177/0969733009351951.

32. Kirilmaz H, Akbolat M, Kahraman G. A research about the ethical sensitivity of healthcare professionals. IJSR 2015; 3(3): 7382.

33. Başak T, Uzun Ş, Arslan F. Yoğun bakım hemşirelerinin etik duyarlılıklarının incelenmesi [Investigation of the moral sensibility of intensive care nurses]. Gülhane Tip Dergi [Gülhane Med J] 2010; 52(2): 76-81 (in Turkish). 